\title{
Membaca Arah Perubahan Tata Kelola Kehutanan Pasca-terbitnya Undang-Undang Cipta Kerja
}

\author{
Ardiyanto Wahyu Nugroho ${ }^{1}$
}

\begin{abstract}
Abstrak
Sektor kehutanan menjadi salah satu sektor yang diubah dalam Undang-Undang No. 11 tahun 2020 tentang Cipta Kerja (UU CK). Revisi Undang-Undang No. 41 tahun 1999 tentang Kehutanan dilakukan karena sektor kehutanan masih dinilai sebagai sektor yang menghasilkan namun memiliki persyaratan perizinan yang rumit. Di sisi lain, pengelolaan hutan di Indonesia masih menemui permasalahanpermasalahan, seper-ti: menurunnya luas tutupan hutan, deforestasi, penyerobotan kawasan hutan, pem-balakan liar, dan kebakaran hutan, yang bermuara pada peningkatan emisi karbon. Oleh karena itu, artikel ini akan mengeksplorasi arah perubahan tata kelola kehutan-an pasca-terbitnya UU CK, apakah mengatasi masalah-masalah pengelolaan hutan yang telah ada sebelumnya atau justru memperparah keadaan. Menariknya, peruba-han tata kelola kehutanan pascaterbitnya UU CK menunjukkan dua sisi yang saling berlawanan.
\end{abstract}

Kata kunci: UU cipta kerja, kehutanan, emisi karbon

\begin{abstract}
Forestry is one of the sectors revised by Law no. 11 of 2020 on Job Creation. Revision of Law no. 41 of 1999 on forestry is due to the forestry sector being considered a promising investment sector, yet it had complicated permits. On the other hand, forest governance faces some problems, such as decreasing forest cover, deforestation, land annexation, illegal logging, and forest fire, which resulted in rising carbon emissions. Therefore, this article will explore the shifting of forest governance direction post the enactment of the Job Creation Law, whether it addresses forest governance problems or makes it worse. In summary, the shifting of forest governance post-job creation law shows two opposite sides.
\end{abstract} Keywords: job creation law, forestry, carbon emission

\section{Pendahuluan}

Salah satu tujuan utama Pemerintah ja (UUCK) adalah menciptakan lapangan Indonesia menerbitkan Undang-Undang pekerjaan baru bagi rakyat dengan cara Nomor 11 Tahun 2020 tentang Cipta Ker- memperbaiki iklim investasi di negara

\footnotetext{
${ }^{1}$ Penulis merupakan peneliti muda yang bekerja di instansi pemerintah di bidang kehutanan.
} 
ini. ${ }^{2}$ Pengundangan UU CK juga diharapkan mampu mempersingkat proses birokrasi dalam berinvestasi baik dari dalam maupun luar negeri ataupun ketika memulai usaha. ${ }^{3}$ lebih lanjut, percepatan proses birokrasi dalam berinvestasi dilakukan dengan merevisi sejumlah pasal dari total 79 undang-undang dalam UU CK agar mempercepat perizinan.

Lebih lanjut, sektor kehutanan menjadi salah satu sektor yang diubah dalam UU CK. Sejumlah pasal Undang-Undang Nomor 41 Tahun 1999 tentang Kehutanan (UU Kehutanan) direvisi. Revisi dilakukan karena sektor kehutanan masih dinilai sebagai sektor yang menghasilkan ${ }^{3}$ namun memiliki persyaratan perizinan yang rumit. Sehingga, penyederhanaan birokrasi diperlukan untuk meningkatkan investasi dan menciptakan lapangan kerja baru di sektor ini. ${ }^{4}$ Sebagai ilustrasi, sebelum terbit UU CK, satu perizinan hanya berlaku untuk satu usaha, tetapi setelah UU CK terbit satu perizinan dapat digunakan untuk multiusaha. ${ }^{5}$

Di sisi lain, saat ini masih terdapat sejumlah permasalahan besar pada pengelolaan hutan di Indonesia, seperti: menurunnya luas tutupan hutan, deforestasi, penyerobotan kawasan hutan, pembalakan liar, dan kebakaran hutan, yang bermuara pada peningkatan emisi karbon. ${ }^{6}$ Oleh karena itu, artikel ini akan mengeksplorasi arah perubahan tata kelola kehutanan pasca-terbitnya UU CK, apakah mengatasi masalah-masalah kehutanan yang telah ada sebelumnya atau justru memperparah keadaan. Setelah pendahuluan, bagian kedua akan membahas Perubahan UU Kehutanan dalam UU CK dan dampaknya pada tata kelola hutan serta lingkungan. Kemudian, bagian ketiga akan menganalisis apakah UU CK mengatasi masalah tata kelola hutan. Terakhir, tulisan ini akan ditutup oleh kesimpulan dan saran.

\section{Perubahan UU Kehutanan dalam UU CK dan dampaknya Pada Tata Kelola Hutan Serta Lingkungan}

UU CK mengubah sebanyak 18 pasal UU Kehutanan, dimana 9 pasal di anta-

\footnotetext{
${ }^{2}$ Indonesia (a), Undang-Undang Tentang Cipta Kerja, UU No. 11 Tahun 2020, LN No.245 Tahun 2020, TLN No.6573 Tahun 2020, Pasal 3 huruf a.

${ }^{3}$ Kementerian Lingkungan Hidup dan Kehutanan (a), Statistik Kementerian Lingkungan Hidup Dan Kehutanan 2019 (Jakarta, Indonesia, 2020) diakses pada https:/ / www.menlhk.go.id/ / site/download_ file?file=1608002226.pdf

${ }^{4}$ Kementerian Koordinator Bidang Perekonomian, Naskah Akademis RUU Tentang Cipta Kerja (Jakarta, Indonesia, 2020), diakses pada https://uu-ciptakerja.go.id/wp-content/uploads/2020/11/Naskah-Akademis-RUU-tentang-Cipta-Kerja.pdf.

${ }^{5}$ Ibid.

${ }^{6}$ Mari Mulyani and Paul Jepson, "Does the 'One Map Initiative'Represent a New Path for Forest Mapping in Indonesia?" Assessing the Contribution of the REDD+ Initiative in Effecting Forest Governance Reform', Forests, 8.1 (2017), 14. Diakses pada https://www.mdpi.com/1999-4907/8/1/14/pdf
} 
ranya berkaitan langsung dengan pengelolaan kawasan hutan lindung dan hutan produksi. Namun, dalam penelitian ini hanya akan dibahas sejumlah hal, yaitu: perubahan ketentuan proporsi luas kawasan hutan yang dipertahankan; penyederhanaan izin pemanfaatan hutan lindung dan hutan produksi; potensi investasi asing dalam pemanfaatan kawasan hutan lindung, dan pengarusutamaan perhutanan sosial. Hal ini karena luasnya cakupan bahasan dampak perubahan UU CK terhadap tata kelola hutan Indonesia, serta sejumlah peraturan turunan UU CK terkait sektor kehutanan masih dalam proses pembuatan.

\section{Perubahan Ketentuan Proporsi Luas Kawasan Hutan yang Diper- tahankan}

Pertama, UU CK mengubah Pasal 18 UU Kehutanan dengan menghapuskan ketentuan mengenai luas minimal kawasan hutan yang harus dipertahankan, yaitu $30 \%$ per Daerah AliranSungai (DAS) atau pulau secara proporsional (Tabel 1). Sebelumnya, penetapan luas minimal kawasan hutan yang harus dipertahankan 30\% diberlakukan sejak Undang-undang Pokok Kehutanan No. 5 tahun 1967 yang mengadopsi sebagian pengelolaan hutan Hindia Belanda. Kemudian, pengaturan ini diteruskan pada UU No 41 tahun 1999.7 Namun, pengaturan ini sebenarnya tidak didukung dengan dasar ilmiah. ${ }^{8}$

Tabel 6. Perubahan pada Pasal 18 Undang-undang No. 41 Tahun 1999 tentang Kehutanan oleh Undang-undang No. 11 Tahun 2020 tentang Cipta Kerja

\begin{tabular}{|r|r|}
\hline \multicolumn{1}{|c|}{ UU No. 41 Tahun 1999 tentang Kehutanan } & UU No. 11 Tahun 2020 tentang Cipta Kerja \\
\hline Pasal 18 & Pasal 18 \\
(1) Pemerintah menetapkan dan mempertahank- & (1) Pemerintah Pusat menetapkan dan memper- \\
an kecukupan luas kawasan hutan dan penu- & tahankan kecukupan luas kawasan hutan dan \\
tupan hutan untuk setiap daerah aliran sun- & penutupan hutan untuk setiap daerah aliran \\
gai, dan atau pulau guna optimalisasi manfaat & sungai, dan/atau pulau guna pengoptimalan \\
lingkungan, manfaat sosial, dan manfaat & manfaat lingkungan, manfaat sosial, dan man- \\
ekonomi masyarakat setempat. & faat ekonomi masyarakat setempat. \\
& \\
\hline
\end{tabular}

${ }^{7}$ Ibid.

8 Pungky Widiaryanto, “Rasionalitas Kebijakan Konsepsi Hutan Dan Penghapusan Batas Minimal Kawasan Hutan 30 Persen", GEMA PUBLICA: Jurnal Manajemen Dan Kebijakan Publik, Vol 5. No. 2 (2020), 140-55. diakses pada https://doi.org/https://doi.org/10.14710/gp.5.2.2020.140-155. 
(2) Luas kawasan hutan yang harus dipertahankan sebagaimana dimaksud pada ayat (1) minimal 30\% (tiga puluh persen) dari luas daerah aliran sungai dan atau pulau dengan sebaran yang proporsional.
(2) Pemerintah Pusat mengatur luas kawasan yang harus dipertahankan sesuai dengan kondisi fisik dan geografis daerah aliran sungai dan/atau pulau.

(3) Ketentuan lebih lanjut mengenai luas kawasan hutan yang harus dipertahankan ialah termasuk pada wilayah yang terdapat proyek strategis nasional diatur dalam Peraturan Pemerintah.

Lebih lanjut, naskah akademik Rancangan Undang-Undang tentang Cipta Kerja (RUU CK) menyebutkan bahwa kewajiban mempertahankan kawasan hutan minimal 30\% dianggap tidak relevan dengan perkembangan saat ini. Naskah akademik RUU CK juga memberikan ilustrasi kawasan hutan di Pulau Jawa yang kurang dari 30\% dan mengartikan bahwa penentuan luas minimal kawasan mengikuti kebutuhan provinsi. ${ }^{9}$

Selanjutnya, UU CK mengubah pengaturan mengenai luas minimal kawasan hutan dengan menyesuaikan kondisi fisik dan geografis DAS atau pulau tersebut. ${ }^{10}$ Dengan demikian, penetapan luas minimal kawasan hutan dalam UU CK akan bergantung pada kondisi fisik dan geografis masing-masing DAS atau pulau. Artinya, setiap DAS atau pulau bisa mempunyai luas hutan lebih atau kurang dari 30\% sesuai dengan kondisi fisik dan geografisnya.

Namun, penyesuaian kondisi fisik dan geografis untuk mempertahankan luas minimal kawasan hutan ini tidak dijelaskan secara detail dalam UU CK, melainkan, Peraturan Pemerintah No. 23 Tahun 2021 Tentang Penyelenggaraan Kehutanan (PP No. 23 Tahun 2021). PP No. 23 Tahun 2021 mengatur bahwa kawasan hutan dan penutupan hutan yang harus dipertahankan memperhatikan sebaran yang proporsional dengan mempertimbangkan 4 hal, yaitu: (a) biogeofisik; (b) daya dukung dan daya tampung lingkungan; (c) karakteristik DAS; dan (d) keanekaragaman flora dan fauna. ${ }^{11}$ Kemudian, kondisi biogeofisik diartikan sebagai: (1) tutupan hutan atau kondisi vegetasi; dan (2) keanekaragaman hayati. Selanjutnya, kondisi bio-

\footnotetext{
${ }^{9}$ Kementerian Koordinator Bidang Perekonomian. Op.Cit., hlm. 1347 Matriks Analisis RUU

${ }^{10}$ Indonesia (a), Op.Cit., Pasal 36.

${ }^{11}$ Indonesia (b), Peraturan Pemerintah Tentang Penyelenggaraan Kehutanan, PP No. 23 Tahun 2021, LN No. 33, TLN No. 6635, 2021, pasal 41.
} 
geofisik berdasarkan geografisnya direpresentasikan sebagai ekoregion geofisik meliputi: (a) kelerengan; (b) curah hujan; dan (c) jenis tanah. ${ }^{12}$ Dengan demikian, faktor kuncinya adalah bagaimana menentukan kondisi fisik dan geografis itu sendiri yang berbeda-beda pada masing-masing sungai di masing-masing pulau.

Penggunaan kriteria kondisi fisik dan geografis dalam UU CK memiliki dua sisi. Di satu sisi, perubahan kriteria ini menunjukkan adanya perkembangan dalam pembuatan kebijakan nasional dan momentum untuk mencapai keseimbangan ekologis. Luas tutupan hutan harus disesuaikan dengan wilayah DAS secara proporsional berdasarkan kondisi fisik dan geografis agar mampu mengontrol air hujan. Hal ini karena kecukupan luas hutan sebuah pulau perlu dihubungkan antara dinamika perubahan tutupan hutan dengan peristiwa banjir yang terjadi di pulau tersebut sebagai indikator. Lebih lanjut, fungsi hutan yang salah satunya sebagai regulator air di sepanjang DAS perlu diperhatikan. Artinya, ketika hujan, hutan harus mampu menyerap air dan sebaliknya, ketika kemarau, air ma- sih mengalir dengan stabil..$^{13}$

Di sisi lain, penghapusan persentase luas minimal kawasan hutan yang harus dipertahankan berpotensi pada penurunan luas hutan Indonesia lebih jauh dan tidak terkontrol. ${ }^{14}$ Artinya, afirmasi untuk mempertahankan hutan di suatu wilayah untuk melindungi fungsi ekologis kawasan tersebut hilang. ${ }^{15}$ Tidak hanya itu, program perhutanan sosial dan reforma agraria di pulau yang hutannya kurang dari 30\% berpotensi akan semakin sulit. ${ }^{16}$

\section{A. Penyederhanaan Izin Pemanfaatan Hutan Lindung dan Hutan Produksi}

Kedua, UU CK menyederhanakan jenis-jenis izin usaha pemanfaatan hutan lindung dan hutan produksi yang ada dalam UU Kehutanan menjadi Perizinan Berusaha (Tabel 2). Artinya, pemanfaatan hutan lindung dan hutan produksi dapat dilakukan hanya dengan memiliki Perizinan Berusaha saja, tidak perlu lagi memiliki beberapa izin usaha. Selain itu, UU CK menegaskan bahwa kewenangan pemberian Perizinan Berusaha merupakan kewenangan pemerintah pusat.

\footnotetext{
${ }^{12}$ Ibid., Penjelasan Pasal 41.

${ }^{13}$ I.B Pramono, Orasi Pengukuhan Profesor Riset Bidang Hidrologi Hutan: Peningkatan Peran Hutan Dalam Mengendalikan Hasil Air Untuk Mitigasi Banjir Dan Kekeringan, ed. by I Rahmawati (Bogor, Indonesia: Badan Penelitian, Pengembangan dan Inovasi Kementerian Lingkungan Hidup dan Kehutanan, 2020) https:/ / library.forda-mof.org/libforda/foto_ebook/ORASI_IRFAN_Final-1.pdf. hlm 1-2

${ }^{14}$ Forest Digest, "Lembar Fakta Omnimbus Law", Report, 2020, hlm 12. https:/ / www.forestdigest. com/detail/842/analisis-isi-uu-cipta-kerja diakses pad tanggal 27 Januari 2020.

${ }^{15}$ Ibid., hlm 12.

${ }^{16}$ Ibid., hlm 15.
} 
Tabel 7. Perubahan pada Pasal 26 Undang-undang No. 41 Tahun 1999 tentang Kehutanan oleh Undang-undang No. 11 Tahun 2020 tentang Cipta Kerja

\begin{tabular}{|l|l|}
\hline UU No. 41 Tahun 1999 tentang Kehutanan & UU No. 11 Tahun 2020 tentang Cipta Kerja \\
\hline $\begin{array}{l}\text { Pasal } 26 \\
\begin{array}{l}\text { (2) Pemanfaatan hutan lindung dilaksanakan } \\
\text { melalui pemberian izin usaha pemanfaatan } \\
\text { kawasan, izin usaha pemanfaatan jasa } \\
\text { lingkungan, dan izin pemungutan hasil } \\
\text { hutan bukan kayu. }\end{array}\end{array}$ & $\begin{array}{l}\text { Pasal } 26 \\
\text { (2) Pemanfaatan hutan lindung sebagaimana di- } \\
\text { maksud pada ayat (1) dilakukan dengan pem- } \\
\text { berian Perizinan Berusaha dari Pemerintah } \\
\text { Pusat. }\end{array}$ \\
\hline $\begin{array}{l}\text { Pasal } 28 \\
\text { (2) Pemanfaatan hutan produksi dilaksanakan } \\
\text { melalui pemberian izin usaha pemanfaatan } \\
\text { kawasan, izin usaha pemanfaatan jasa } \\
\text { lingkungan, izin usaha pemanfaatan hasil } \\
\text { hutan kayu, izin usaha pemanfaatan hasil } \\
\text { hutan bukan kayu, izin pemungutan ha- } \\
\text { sil hutan kayu, dan izin pemungutan hasil } \\
\text { hutan bukan kayu. }\end{array}$ & $\begin{array}{l}\text { Pasal } 28 \\
\text { (2) Pemanfaatan hutan produksi sebagaimana di- } \\
\text { maksud ayat (1) dilakukan dengan pemberian } \\
\text { Perizinan Berusaha dari Pemerintah Pusat. }\end{array}$ \\
\hline
\end{tabular}

Penyederhanaan jumlah perizinan diharapkan memberikan dampak positif berupa efisiensi biaya dan waktu yang diperlukan oleh pelaku usaha untuk memulai usaha di sektor kehutanan. Pasalnya, investor menganggap mekanisme perizinan pemanfaatan kawasan hutan relatif rumit dan panjang. ${ }^{17}$ Namun, dalam perkembangannya, proses pengajuan izin usaha menjadi lebih singkat seiring dengan pergantian peraturan. Pada mulanya, Peraturan Menteri Kehutanan No. P.11 Tahun 2008 Tentang Perubahan Kedua Peraturan Menteri Kehutanan Nomor P.19 Tahun 2007 ten- tang Tata Cara Pemberian Izin dan Perluasan Areal Kerja Usaha Pemanfaatan Hasil Hutan Kayu pada Hutan Tanaman Industri Dalam Hutan Tanaman pada Hutan Produksi, proses pengajuan Izin Usaha Pemanfaatan Hasil Hutan Kayu dalam Hutan Tanaman Industri (IUPHHK-HTI) memerlukan waktu setidaknya 80 hari kerja di luar waktu untuk memperoleh persetujuan Analisis Mengenai Dampak Lingkungan Hidup (AMDAL) atau Upaya Pengelolaan Lingkungan Hidup dan Upaya Pemantauan Lingkungan Hidup (UKL-UPL). ${ }^{18}$ Kemudian, jangka waktu tersebut diubah menjadi

${ }^{17}$ Efrem Siregar, “Duh! Izin Di RI Ribet, Investor Industri Kayu Batal Investasi”, Online News, 2020, diakses pada https://www.cnbcindonesia.com/news/20200103201644-4-127581/duh-izin-di-ri-ribetinvestor-industri-kayu-batal-investasi, diakses 6 April 2020.

${ }^{18}$ Integrated Law Enforcement Approach, “Izin Usaha Pemanfaatan Hasil Hutan Kayu - Hutan Tanaman Industri (HTI)", Website, 2010, diakses pada https://www2.cifor.org/ilea/_ref/ina/indicators/ forestbusiness/Permit/IUPHHK-HTI.htm diakses pada tanggal 16 Juni 2021 
30 hari kerja dengan Peraturan Menteri Lingkungan Hidup dan Kehutanan (Permen LHK) No. P.9 Tahun $2015^{19}$ dan diubah kembali menjadi 18 hari $^{20}$ kerja dengan Permen LHK No. P.28 Tahun 2018. ${ }^{21}$ Sementara, Peraturan Menteri Lingkungan Hidup dan Kehutanan No. 8 Tahun 2021 Tentang Tata Hutan dan Penyusunan Rencana Pengelolaan Hutan, Serta Pemanfaatan Hutan di Hutan Lindung dan Hutan Produksi (Permen LHK No. 8 Tahun 2021) yang merupakan peraturan turunan UU CK membuat jangka waktu penerbitan izin menjadi 39 hari kerja. ${ }^{22}$

Permen LHK No. 8 Tahun 2021 juga menggabungkan pengaturan beberapa jenis pemanfaatan kawasan hutan yang sebelumnya diatur dalam peraturan menteri yang berbeda. Sebagai contoh, sebelumnya pemanfaatan jasa lingkungan wisata alam di hutan lindung diatur dalam Peraturan Menteri Kehutanan No. P.22 Tahun 2012, ${ }^{23}$ sedangkan pemanfaatan jasa lingkungan wisata alam di hutan produksi diatur dalam Peraturan Menteri Lingkungan Hidup dan Kehutanan No. P.31 Tahun 2016, ${ }^{24}$ dan IUPHHK Restorasi Ekosistem diatur dalam Peraturan Menteri Lingkungan Hidup dan Kehutanan No. P.28 Tahun 2018. ${ }^{25}$ Sekarang, semua peraturan yang tersebar itu telah dinyatakan tidak berlaku lagi. ${ }^{26}$

Lebih lanjut, PP No. 23 Tahun 2021 dan Permen LHK No. 8 Tahun 2021 menegaskan adanya peluang Multiusaha Kehutanan dalam pemanfaatan hutan lind-

\footnotetext{
${ }^{19}$ Indonesia (c), Peraturan Menteri Lingkungan Hidup dan Kehutanan No. P.9/Menlhk-II/ 2015 Tentang Tata Cara Perpanjangan Izin Usaha Pemanfaatan Hasil Hutan Kayu Dalam Hutan Alam, Izin Usaha Pemanfaatan Hasil Hutan Kayu Restorasi Ekosistem atau Izin Usaha Pemanfaatan Hasil Hutan Kayu Hutan Tanaman Industri pada Hutan Produksi. Berita Negara No. 471. Tahun 2015. Peraturan ini juga diperkenalkan sistem pendaftaran perizinan secara online (pasal 5 ayat (2).

${ }^{20}$ ADA tambahan waktu untuk verifikasi lapangan dengan waktu yang tidak ditentukan dalam aturan tersebut.

${ }^{21}$ Indonesia (d), Peraturan Menteri Lingkungan Hidup dan Kehutanan tentang Tata Cara Pemberian, Perluasan Areal Kerja dan Perpanjangan lzin Usaha Pemanfaatan Hasil Hutan Kayu dalam Hutan Alam, Izin Usaha Pemanfaatan Hasil Hutan Kayu Restorasi Ekosistem atau Izin Usaha Pemanfaatan Hasil Hutan Kayu Hutan Tanaman Industri pada Hutan Produksi, No. P.28/MENLHK/SETJEN/KUM.1/7/2018. Berita Negara No. 1120 Tahun 2018.

${ }^{22}$ Indonesia (e), Peraturan Menteri Lingkungan Hidup dan Kehutanan Tentang Tata Hutan dan Penyusunan Rencana Pengelolaan Hutan, Serta Pemanfaatan Hutan di Hutan Lindung dan Hutan Produksi, No. 8 Tahun 2021. Berita Negara No. 319 Tahun 2021. Pasal 61-70.

${ }^{23}$ Indonesia (f), Peraturan Menteri Kehutanan Tentang Pedoman Kegiatan Usaha Pemanfaatan Jasa Lingkungan Wisata Alam di Hutan Lindung, Nomor. P.22/ MENHUT-II/2012 2012. Berita Negara No. 543 Tahun 2012.

${ }^{24}$ Indonesia (g), Peraturan Menteri Lingkungan Hidup dan Kehutanan tentang Pedoman Kegiatan Usaha Pemanfaatan Jasa Lingkungan Wisata Alam pada Hutan Produksi, Nomor P.31/MENLHK/SETJEN/ KUM.1/3/2016, Berita Negara Nomor 369. Tahun 2016

${ }^{25}$ Indonesia, Peraturan Menteri Lingkungan Hidup dan Kehutanan No. P. 28 Tahun 2018.

${ }^{26}$ Indonesia (e). Op.Cit., Pasal 395.
} 
ung dan hutan produksi. ${ }^{27}$ Multiusaha kehutanan adalah penerapan beberapa kegiatan usaha Kehutanan secara bersamaan untuk mengoptimalkan Kawasan Hutan. Artinya, pemegang Perizinan Berusaha dapat mengusahakan beberapa usaha kehutanan seperti usaha pemanfaatan kawasan, usaha pemanfaatan hasil hutan kayu dan bukan kayu, dan/ atau usaha pemanfaatan jasa lingkungan secara bersamaan.

Di sisi lain, ketentuan tersebut menuai kritik dapat mengafirmasi ketimpangan pemanfaatan hasil hutan antara masyarakat tradisional dan pengusaha besar pada hutan lindung. ${ }^{28}$ Pengusaha besar menjadi lebih mudah untuk memanfaatkan hutan lindung dan menguasai hutan untuk diusahakan dengan berbagai kegiatan. Lebih lanjut, ketentuan multiusa- ha akan menyulitkan penentuan dampak dan manfaat bagi masyarakat serta pengawasannya. ${ }^{29}$

\section{B. Potensi Investasi Asing pada Pe- manfaatan Kawasan Hutan Lindung}

Ketiga, UU CK memberikan kemungkinan dipermudahnya investasi asing masuk dalam pengelolaan hutan lindung. Sebelumnya, UU Kehutanan menggunakan redaksi "badan usaha milik swasta Indonesia" sebagai salah satu subjek hukum yang dapat memperoleh izin pemanfaatan jasa lingkungan. Kemudian, UU CK menghapuskan diksi "Indonesia" dalam ketentuan tersebut (Tabel 3). ${ }^{30}$ Artinya, badan usaha milik swasta asing dapat mengajukan izin pemanfaatan jasa lingkungan di hutan lindung.

Tabel 8. Perubahan pada pasal 27 Undang-undang No. 41 Tahun 1999 tentang Kehutanan oleh Undang-undang No. 11 Tahun 2020 tentang Cipta Kerja

\begin{tabular}{|c|c|c|}
\hline & $\begin{array}{l}\text { UU No. } 41 \text { Tahun } 1999 \text { tentang Ke- } \\
\text { hutanan }\end{array}$ & $\begin{array}{c}\text { UU No. } 11 \text { Tahun } 2020 \text { tentang Cipta } \\
\text { Kerja }\end{array}$ \\
\hline (2) & $\begin{array}{l}\text { Pasal } 27 \\
\text { Izin usaha pemanfaatan kawasan se- } \\
\text { bagaimana dimaksud dalam Pasal } 26 \\
\text { ayat (2) dapat diberikan kepada: a per- } \\
\text { orangan, b. koperasi. }\end{array}$ & $\begin{array}{l}\text { Pasal } 27 \\
\text { (1) Perizinan Berusaha sebagaimana di- } \\
\text { maksud dalam Pasal } 26 \text { ayat (2) dapat } \\
\text { diberikan kepada: }\end{array}$ \\
\hline
\end{tabular}

\footnotetext{
${ }^{27}$ Indonesia (b), Op.Cit., Pasal 132 jo. Pasal 149 jo Indonesia (e), Op.Cit., Pasal 108 jo. Pasal 137.

${ }^{28}$ Forest Digest, Op.Cit., hlm. 19.

${ }^{29}$ Ibid.

${ }^{30}$ Indonesia (a), Op.Cit., hlm 2. Pasal 36.
} 
(3) Izin usaha pemanfaatan jasa lingkungan sebagaimana dimaksud dalam Pasal 26 ayat (2), dapat diberikan kepada:

a perorangan,

b koperasi,

c badan usaha milik swasta Indonesia,

d badan usaha milik negara atau badan usaha milik daerah.

Izin pemungutan hasil hutan bukan kayu sebagaimana dimaksud dalam Pasal 26 ayat (2), dapat diberikan kepada: a. perorangan, $b$. koperasi
a. perseorangan;
b. koperasi;
c. badan usaha milik negara;
d. badan usaha milik daerah; atau
e. badan usaha milik swasta

Lebih lanjut, penanam modal asing hanya dapat dilakukan pada usaha besar dengan nilai investasi lebih dari Rp10 Miliar di luar nilai tanah dan bangunan, serta berbentuk perseroan terbatas berdasarkan hukum Indonesia dan berkedudukan di Indonesia. ${ }^{31}$ Namun, pemungutan hasil hutan non-kayu seperti getah pinus, bambu, gaharu, rotan dan lainnya dikategorikan sebagai bidang usaha yang dialokasikan untuk UMKM (Usaha Mikro, Kecil, dan Menengah). ${ }^{32}$ Lebih jauh lagi, Permen LHK No. 3 Tahun 2021 tentang Standar Kegiatan Usaha Pada Penyelenggaraan Perizinan Berusaha Berbasis Risiko Sektor Lingkungan Dan Kehutanan menyebutkan bahwa kegiatan usaha pemanfaatan hutan lindung tidak membe- dakan penggolongan usaha dan seluruh penanam modal dapat melakukan usaha. ${ }^{33}$ Dengan demikian, penanam modal asing dapat berinvestasi dalam kegiatan usaha pemanfaatan hutan lindung. Namun, kesimpulan ini perlu dikonfirmasi kembali kepada Badan Koordinasi Penanaman Modal (BKPM).

Konsekuensinya, di satu sisi banyak modal asing yang mungkin akan masuk ke sektor ini. Di sisi lain, persaingan antara usaha kecil dan besar akan terjadi secara sempurna dalam pemanfaatan hutan lindung dan mengafirmasi ketimpangan pemanfaatan hutan lindung antara masyarakat dan pengusaha besar. Akses kelola masyarakat akan semakin sempit karena bersaing dengan pengusaha besar.

\footnotetext{
${ }^{31}$ Indonesia. Presiden RI, Peraturan Presiden No. 10 Tahun 2021 Tentang Bidang Usaha Penanaman Modal, LN No. 61 Tahun 2021, Pasal 7.

${ }^{32}$ Ibid. lampiran II..

${ }^{33}$ Indonesia. Peraturan Menteri Lingkungan Hidup dan Kehutanan Tentang Standar Kegiatan Usaha pada Penyelenggaraan Perizinan Berusaha Berbasis Risiko Sektor Lingkungan Hidup dan Kehutanan, No.3 Tahun 2021. Berita Negara No. 270 Tahun 2021. Lampiran hlm. 15.
} 


\section{Pengarusutamaan Perhutanan Sosial}

Keempat, UU CK menyelipkan pasal 29A pada UU Kehutanan (tabel 4) yang mengatur mengenai perhutanan sosial. Sebelumnya, ketentuan mengenai perhutanan sosial tidak ada dalam UU Kehutanan, melainkan tersebar dalam peraturan pemerintah dan terkodifikasi di Peraturan Menteri Lingkungan Hidup dan Kehutanan No. P. 83/MenLHK/Setjen/Kum.1/10/2016 tentang Perhutanan Sosial. Tentunya, ini merupakan hal baik karena program perhutanan sosial menjadi arus utama dan mungkin mendapatkan posisi yang lebih kuat dalam penganggaran.
Namun, pada peraturan-peraturan perhutanan sosial sebelumnya subjek pemohon perhutanan sosial terbatas pada petani atau kelompok tani atau koperasi tani/desa. Pemohon perseorangan ada sebagai pemohon Izin Usaha Pemanfaatan Hasil Hutan Kayu Pada Hutan Tanaman Rakyat/IUPHHK-HTR, tetapi terbatas pada perseorangan yang memiliki pendidikan kehutanan atau bidang ilmu lainnya yang pernah sebagai pendamping atau penyuluh yang pernah bekerja di bidang kehutanan dengan membentuk kelompok atau koperasi bersama masyarakat setempat. ${ }^{34}$

Tabel 9. Penambahan pasal 29A Undang-undang No. 41 Tahun 1999 tentang Kehutanan oleh Undang-undang No. 11 Tahun 2020 tentang Cipta Kerja

\begin{tabular}{|l|l|}
\hline $\begin{array}{l}\text { UU No. } 41 \text { Tahun } 1999 \text { tentang Ke- } \\
\text { hutanan }\end{array}$ & $\begin{array}{l}\text { UU No. } 11 \text { Tahun } 2020 \text { tentang Cipta Ker- } \\
\text { ja }\end{array}$ \\
\hline & $\begin{array}{l}\text { Pasal 29A } \\
\text { 1. Pemanfaatan hutan lindung dan hutan } \\
\text { produksi sebagaimana dimaksud }\end{array}$ \\
& $\begin{array}{l}\text { dalam Pasal 26 dan Pasal 28 dapat } \\
\text { dilakuan kegiatan Perhutanan sosial. }\end{array}$ \\
& $\begin{array}{l}\text { 2. Perhutanan sosial sebagaimana di- } \\
\text { maksud pada ayat (1) dapat diberikan } \\
\text { kepada: }\end{array}$ \\
& $\begin{array}{l}\text { a. perseorangan; } \\
\text { b. kelompok tani hutan; dan } \\
\text { c. koperasi. }\end{array}$ \\
\hline
\end{tabular}

${ }^{34}$ Pasal 30 ayat (1) huruf e permen LHK No. P. 83/MenLHK/Setjen/Kum.1/10/2016. 
Dengan demikian, Pasal 29A ini menimbulkan setidaknya dua polemik. Pertama, unsur kegiatan perhutanan sosial tidak dijelaskan. Sementara, pasal ini akan berpengaruh pada pengaturan perhutanan sosial yang bertujuan untuk mengurangi kemiskinan, pengangguran, dan ketimpangan pengelolaan/pemanfaatan kawasan hutan bagi masyarakat. ${ }^{35}$ Kedua, terbukanya peluang perseorangan sebagai pemohon perhutanan sosial dapat membuka peluang percaloan ${ }^{36}$ dan melanggengkan ketimpangan pengelolaan kawasan hutan. Sementara, posisi masyarakat adat tidak terlihat dalam UU Kehutanan ini.

\section{Arah Perubahan Tata Kelola Ke- hutanan Pasca-terbitnya Undang- -Undang Cipta Kerja}

Empat uraian perubahan ketentuan UU Kehutanan dalam UU CK di atas menunjukkan bahwa perubahan ketentuan tersebut memiliki dua sisi. Di satu sisi, perubahan ketentuan tersebut memberikan dampak positif pada investasi karena menyederhanakan perizinan, memungkinkan multiusaha, dan memungkinkan masuknya investasi asing. Di sisi lain, perubahan ketentuan tersebut memberikan dampak negatif pada pengelolaan sumber daya alam karena menghilangkan afirmasi untuk mempertahankan hutan di suatu wilayah, mengafirmasi dan melanggengkan ketimpangan pemanfaatan hasil hutan antara masyarakat tradisional dan pengusaha besar, serta meminggirkan masyarakat adat. Namun, dampak-dampak tersebut belum terlihat secara nyata karena peraturan-peraturan yang ada ini belum beroperasional secara efektif. Sehingga, penelitian lanjutan mengenai dampak UU CK pada pengelolaan hutan diperlukan ketika peraturan turunannya sudah lengkap dan sudah diimplementasikan.

Walaupun begitu, permasalahan-permasalahan pada pengelolaan hutan yang telah ada sebelumnya jelas terlihat tidak diatasi dalam perubahan norma UU Kehutanan dalam UU CK. Sebaliknya, UU CK dapat memperparah kenaikan emisi karbon seiring peningkatan investasi dalam pemanfaatan hutan produksi. ${ }^{37} \mathrm{Hal}$ ini mengingat sumber emisi karbon paling besar di Indonesia berasal dari sektor kehutanan terutama akibat alih fungsi lahan hutan dan kebakaran. ${ }^{38}$

\footnotetext{
${ }^{35}$ Ibid., bagian menimbang.

${ }^{36}$ Forest digest, Op.Cit., hlm. 21.

${ }^{37}$ Rina Muhayah Noor Fitri, "Reduksi Emisi Karbon Melalui Pengelolaan Hutan Alam Produksi Lestari”, Jurnal Hutan Tropis, 1.1 (2013) diakses pada https://ppjp.ulm.ac.id/journal/index.php/jht/ article/download/1487/1277.

${ }^{38}$ Kementerian Lingkungan Hidup dan Kehutanan, Indonesia Third National Communication: Under the UNFCCC, ed. by N Masripatin (Jakarta, Indonesia: Ministry of Environment and Forestry, 2018) diakses pada https://unfccc.int/sites/default/files/resource/8360571_Indonesia-NC3-2-Third Na-
} 
Lebih lanjut, tren emisi di sektor kehutanan konsisten sejak tahun 1990 hingga sekarang, ${ }^{39}$ dengan laju deforestasi per tahun pada 2017-2018 adalah 0.44 juta ha. ${ }^{40}$ Ditambah, peningkatan investasi pada Hutan Tanaman Industri (HTI) yang dilakukan pada hutan produksi dengan jenis hutan sekunder dapat mengakibatkan peningkatan emisi karbon, Hal ini disebabkan penebangan tumbuhan hutan sekunder untuk membangun hutan tanaman melepaskan emisi karbon yang sebelumnya tersimpan di dalam hutan. ${ }^{41}$ Sebaliknya, apabila pembangunan HTI diarahkan di kawasan hutan produksi yang terdegradasi, maka pembangunan hutan tanaman baru akan menyerap karbon sekaligus menurunkan emisi karbon nasional dan manfaat ekonomi lainnya. ${ }^{42}$ Hal ini juga didukung oleh luasan kawasan hutan produksi non-hutan $(12,2$ juta ha) yang lebih luas daripada kawasan hutan produksi di hutan sekunder $(9,6$ juta ha), yang dapat dilihat pada Tabel 5 .

Tabel 10. Luas dan tipologi kawasan hutan Indonesia tahun 2019

\begin{tabular}{|l|l|l|l|l|l|}
\hline $\begin{array}{l}\text { Kawasan } \\
\text { hutan }\end{array}$ & $\begin{array}{l}\text { Hutan Kon- } \\
\text { servasi (ribu } \\
\text { ha) }\end{array}$ & $\begin{array}{l}\text { Hutan Lind- } \\
\text { ung (ribu } \\
\text { ha) }\end{array}$ & $\begin{array}{l}\text { Hutan } \\
\text { Produksi } \\
\text { Terbatas } \\
\text { (ribu ha) }\end{array}$ & $\begin{array}{l}\text { Hutan Pro- } \\
\text { duksi (ribu } \\
\text { ha) }\end{array}$ & $\begin{array}{l}\text { Hutan } \\
\text { Produksi } \\
\text { Konversi } \\
\text { (ribu ha) }\end{array}$ \\
\hline $\begin{array}{l}\text { Hutan } \\
\text { Primer }\end{array}$ & $12,466.5$ & $15,829.8$ & $9,877.1$ & $4,586.2$ & $2,460.9$ \\
\hline $\begin{array}{l}\text { Hutan } \\
\text { Sekunder }\end{array}$ & $4,726.9$ & $7,753.5$ & $11,060.7$ & $9,692.7$ & $3,781.9$ \\
\hline $\begin{array}{l}\text { Hutan Ta- } \\
\text { naman }\end{array}$ & 122.4 & 288.1 & 283.0 & $2,664.1$ & 28.4 \\
\hline Non-Hutan & $4,571.5$ & $5,789.7$ & $5,567.1$ & $12,259.0$ & $6,576.3$ \\
\hline Jumlah & $\mathbf{2 1 , 8 8 7 . 3}$ & $\mathbf{2 9 , 6 6 1 . 1}$ & $\mathbf{2 6 , 7 8 7 . 9}$ & $\mathbf{2 9 , 2 0 2 . 0}$ & $\mathbf{1 2 , 8 4 7 . 5}$ \\
\hline
\end{tabular}

Sumber: Diolah dari Statistik Lingkungan Hidup dan Kehutanan (2019) ${ }^{43}$

tional Communicat ion - Indonesia - editorial refinement 13022018.pdf

${ }^{39}$ Mengpin Ge and Johannes Friedrich. Op.cit. Bagian Global Historical Emissions

${ }^{40}$ Kementerian Lingkungan Hidup dan Kehutanan (c), Statistik Lingkungan Hidup Dan Kehutanan Tahun 2018 (Jakarta, Indonesia, 2019) https:// www.menlhk.go.id// site/download_file?file=1574395305. pdf.

${ }^{41}$ Menurut Perdirjen PTKL No. P.1/VII-IPSDH/2015, hutan sekunder adalah seluruh kenampakan hutan dataran rendah, perbukitan dan pegunungan yang telah menampakkan bekas penebangan (kenampakan alur dan bercak bekas tebang), termasuk hutan kerdil, kerangas, hutan di batuan kapur, hutan di atas batuan ultra basa, hutan daun jarum, hutan luruh daun dan hutan lumut. Daerah berhutan bekas tebas bakar yang ditinggalkan, bekas kebakaran atau yang tumbuh kembali dari bekas tanah terdegradasi. Bekas tebangan parah bukan areal HTI, perkebunan atau pertanian dimasukkan savanna, semak belukar atau lahan terbuka

${ }^{42}$ I Indartik, N Parlinah, and M Lugina, “Upaya Pembangunan Hutan Tanaman Industri Untuk Penurunan Emisi Karbon", Jurnal Penelitian Sosial Dan Ekonomi Kehutanan, 8.2 (2011), 139-47, diakses pada http:// ejournal.forda-mof.org/ejournal-litbang/index.php/JPSEK/article/view/228/219.

${ }^{43}$ Kementerian Lingkungan Hidup dan Kehutanan (a), Op.Cit., hlm. 10, Tabel 1.2 Rekapitulasi luas 
Selain itu, alih fungsi ekosistem gambut menjadi lahan menghasilkan emisi tahunan tinggi, yaitu $0.77 \mathrm{GtCO}_{2}$-e. ${ }^{44} \mathrm{~Pa}$ dahal, gambut memiliki cadangan karbon yang sangat besar, yaitu sekitar 4000 Mg C per hektar. ${ }^{45}$ Di Indonesia, diperkirakan terdapat sekitar 20.6 juta hektar hutan gambut. Namun, jika gambut dikeringkan untuk dikonversi menjadi lahan pertanian, maka akan terjadi proses aerasi pada gambut yang akan menyebabkan oksidasi dan dekomposisi sehingga menimbulkan emisi karbon. ${ }^{46}$ Lebih lanjut, apabila terbakar maka proses oksidasi gambut menjadi jauh lebih cepat dengan emisi karbon besar. ${ }^{47}$

Lebih jauh lagi, sebagai negara pihak Perjanjian Kerangka Perubahan Iklim Persatuan Bangsa-Bangsa/United Nation Convention on Climate Change (UNFCCC) dan Perjanjian Paris Indonesia telah berkomitmen untuk menurunkan emisi karbon sebagai bagian dari usaha mengendalikan perubahan iklim. ${ }^{48}$ Pemerintah telah menargetkan pengurangan emisi sebesar $29 \%$ dari usaha sendiri atau
41\% dengan bantuan luar negeri pada tahun 2030 dalam Nationally Determined Contribution (NDC). ${ }^{49}$ Pemerintah juga menyatakan bahwa salah satu kunci utama pencapaian target penurunan emisi Indonesia ada di sektor kehutanan sebesar $17,2 \% .{ }^{50}$ Dengan demikian, tata kelola hutan merupakan kunci untuk mencapai target penurunan emisi Indonesia. Namun, peningkatan investasi di sektor kehutanan dengan adanya UU CK dapat menghalangi pencapaian target NDC, bahkan dapat mempercepat perubahan iklim dan/atau memperparah dampak perubahan iklim.

\section{Penutup}

Terbitnya UU CK dan peraturan turunannya telah mengubah beberapa pasal pada UU Kehutanan empat di antaranya adalah perubahan ketentuan proporsi luas kawasan hutan yang dipertahankan; penyederhanaan izin pemanfaatan hutan lindung dan hutan produksi; potensi investasi asing dalam pemanfaatan kawasan hutan lindung, dan pengarusutamaan perhutanan sosial. Menariknya, keempat

penutupan lahan Indonesia di dalam dan luar kawasan hutan.

${ }^{44}$ DNPI \& MC Kinsey, Indonesia's Greenhouse Gas Abatement Cost Curve (Jakarta, 2010) <https:/ / photos.mongabay.com/10/indonesia_ghg_cost_curve_english_sm.pdf>

${ }^{45}$ D Murdiyarso and others, "Cadangan Karbon Di Lahan Gambut", Leaflet, 2017 diakses pada 17 May 2021 di https://core.ac.uk/download/pdf/193250939.pdf.

${ }^{46}$ DNPI \& MC Kinsey,Op.Cit. hlm. 10.

${ }^{47}$ Ibid.

${ }^{48}$ Kementerian Lingkungan Hidup dan Kehutanan (b), Op.Cit. hlm. 3-4 dan iii.

${ }^{49}$ Ibid.

${ }^{50} \mathrm{Ibid}$. 
perubahan ketentuan UU Kehutanan dalam UU CK tersebut memiliki dua sisi.

Di satu sisi, perubahan ketentuan UU Kehutanan dalam UU CK diharapkan dapat memberikan dampak positif pada peningkatan investasi karena menyederhanakan perizinan, memungkinkan multiusaha, dan memungkinkan masuknya investasi asing. Di sisi lain, perubahan ketentuan tersebut memberikan dampak negatif pada pengelolaan sumber daya alam karena menghilangkan afirmasi untuk mempertahankan hutan di suatu wilayah, mengafirmasi dan melanggengkan ketimpangan pemanfaatan hasil hutan antara masyarakat tradisional dan pengusaha besar, serta meminggirkan masyarakat adat.

Lebih lanjut, UU CK tidak mengatasi permasalahan-permasalahan pada pe- ngelolaan hutan yang telah ada sebelumnya. Melainkan, ketentuan UU CK sangat berat pada eksploitasi sumber daya hutan yang dapat memperparah kenaikan emisi karbon seiring peningkatan investasi dalam pemanfaatan hutan.

Namun, dampak-dampak dari terakumulasinya permasalahan pengelolaan hutan yang telah ada sebelumnya dan dampak dati implementasi UU CK pada sektor kehutanan belum terlihat secara nyata. Hal ini disebabkan peraturan-peraturan baru ini belum beroperasional secara efektif. Sehingga, arah perubahan tata kelola kehutanan pasca-terbitnya UU CK belum dapat terlihat dengan jelas. Oleh karena itu, penelitian lanjutan mengenai dampak UU CK pada pengelolaan hutan diperlukan ketika peraturan turunannya sudah lengkap dan sudah diimplementasikan. 


\section{DAFTAR PUSTAKA}

\section{Peraturan Perundang-undangan}

Indonesia. Undang-Undang Kehutanan, UU No. 41 Tahun 1999, LN No. 167 Tahun 1999, TLN No. 3888.

- Peraturan Pemerintah Tentang

Tata Hutan dan Penyusunan Rencana Pengelolaan Hutan serta Pemanfaatan Hutan, No. 6 Tahun 2007, LN No. 22 Tahun 2007, TLN 4696.

- Peraturan Pemerintah Tentang Perubahan Atas Peraturan Pemerintah No. 6 Tahun 2007 Tentang Tata Hutan dan Penyusunan Rencana Pengelolaan Hutan serta Pemanfaatan $\mathrm{Hu}$ tan, UU No. 3 Tahun 2008, LN No. 16 Tahun 2008, TLN No. 4814.

\begin{tabular}{rr} 
Peraturan & Mente- \\
\hline Ki & KehutananTentang
\end{tabular}
man Kegiatan Usaha Pemanfaatan Jasa Lingkungan Wisata Alam di Hutan Lindung, Nomor. P.22/ MENHUT-II/2012 2012. Berita Negara No. 543 Tahun 2012.

Undang-Undang Pemerintahan Daerah, UU No.23 Tahun 2014, LN No. 244 Tahun 2014, TLN No. 5587.

Peraturan Menteri Lingkungan Hidup dan Kehutanan Tentang Tata Cara Perpanjangan Izin Usaha Pemanfaatan Hasil Hutan Kayu Dalam Hutan Alam, Izin Usaha Pemanfaatan Hasil Hutan Kayu Restorasi Ekosistem atau Izin Usaha Pemanfaatan Hasil Hutan Kayu Hutan Tanaman Industri pada Hutan Produk- si, No. P.9/ Menlhk-II/ 2015. Berita Negara No.471. Tahun 2015.

- Peraturan Menteri Lingkungan Hidup dan Kehutanan tentang Pedoman Kegiatan Usaha Pemanfaatan Jasa Lingkungan Wisata A l a m pada Hutan Produksi, No. P.31/ MENLHK/SETJEN/KUM.1/3/2016. Berita Negara Nomor 369. Tahun 2016

- Peraturan Menteri Lingkungan Hidup dan Kehutanan tentang Perhutanan Sosial, No. P. 83 / M e n L HK/Setjen/Kum.1/10/2016.

- Presiden RI, Instruksi Presiden tentang Penundaan dan Evaluasi

Perizinan Serta Peningkatan Produktivitas Perkebunan Sawit, No. 8 Tahun 2018.

- Peraturan Menteri Lingkungan Hidup dan Kehutanan tentang Tata Cara Pemberian, Perluasan Areal Kerja dan Perpanjangan lzin Usaha Pemanfaatan Hasil Hutan Kayu dalam Hutan Alam, Izin Usaha Pemanfaatan Hasil Hutan Kayu Restorasi Ekosistem atau Izin Usaha Produksi, No. P . 28 / MENLHK/SETJEN/KUM.1/7/2018. Berita Negara No. 1120 Tahun 2018 sebagaimana telah diubah dengan Peraturan Menteri Lingkungan Hidup dan Kehutanan Nomor P.19/MENLHK/SETJEN/ KUM.1/4/2019.Indonesia. UndangUndang Cipta Kerja, UU No. 11 Tahun 2020, LN No.245 Tahun 2020, TLN No. 6573. 
Undang-Undang Perubahan Atas Undang-Undang No.4 Tahun 20009 tentang Pertambangan Mineral dan Batubara, UU No. 3 Tahun 2020 , LN No. 147 Tahun 2020, TLN No. 6525.

Kementerian Lingkungan Hidup dan Kehutanan. Direktorat Jenderal Pengelolaan Hutan Produksi Lestari. Peraturan Direktur Jenderal Pengelolaan Hutan Produksi Lestari No. P.1 Tahun 2020 tentang Tata Cara Permohonan, Penugasan dan Pelaksanaan Model Multiusaha Kehutanan Bagi Pemegang Izin Usaha Pemanfaatan Hasil Hutan Kayu Pada Hutan Produksi - Undang-Undang Tentang Cipta Kerja, UU No. 11 Tahun 2020, LN No.245 Tahun 2020, TLN No.6573, 2020 . Peraturan Pemerintah Tentang Penyelenggaraan Kehutanan, $\quad \mathrm{N}$ o . 23 Tahun 2021, LN No. 33, TLN No. 6635.

- Presiden RI, Peraturan Presiden No.10 Tahun 2021 Tentang Bidang Usaha Penanaman Modal. LN No. 61 Tahun 2021.

- Peraturan Menteri Lingkungan Hidup dan Kehutanan Tentang Standar Kegiatan Usaha pada Penyelenggaraan Perizinan Berusaha Berbasis Risiko Sektor Lingkungan Hidup dan Kehutanan, No. 3 Tahun 2021. Berita Negara No. 270 Tahun 2021.

Peraturan Menteri Lingkungan Hidup dan Kehutanan Tentang Pengelolaan Perhutanan Sosial, No. 9 Tahun
2021. Berita Negara No. 320 Tahun 2021.

- Peraturan Menteri Lingkungan Hidup dan Kehutanan Tentang Tata Hutan dan Penyusunan Rencana Pengelolaan Hutan, Serta Pemanfaatan Hutan di Hutan Lindung dan Hutan Produksi, No. 8 Tahun 2021. Berita Negara No. 319 Tahun 2021.

Peraturan Menteri Lingkungan Hidup dan Kehutanan Tentang Daftar Usaha dan/atau Kegiatan Yang Wajib Memiliki Analisis Mengenai Dampak Lingkungan Hidup, No. 4 Tahun 2021 Upaya Pengelolaan Lingkungan Hidup dan Upaya Pemantauan Lingkungan Hidup atau Surat Pernyataan Kesanggupan Pengelolaan dan Pemantauan Lingkungan Hidup. Berita Negara No. 267 Tahun 2021.

\section{Artikel Jurnal dan Media Massa}

Agus, Fahmuddin, Eleonora Runtunuwu, Tania June, Erni Susanti, Herna Komara, Haris Syahbuddin, and others, 'Carbon Dioxide Emission in Land Use Transitions to Plantation', Jurnal Litbang Pertanian, 28 (2009), 119-26

Baccini, AGSJ, S J Goetz, W S Walker, N $\mathrm{T}$ Laporte, M Sun, D Sulla-Menashe, and others, 'Estimated Carbon Dioxide Emissions from Tropical Deforestation Improved by Carbon-Density Maps', Nature Climate Change, 2 (2012), 182-85 <https:/ / doi. org/10.1038/nclimate1354> 
Badan Nasional Penanggulangan Bencana, 'Data Dan Informasi Bencana Indonesia', Database, $2021<\mathrm{h} \mathrm{t} \mathrm{t} \mathrm{-}$ ps:/ / dibi.bnpb.go.id/DesInventar/ main.jsp?countrycode=id\& 1 a $n$ g $=\mathrm{EN}>$ [accessed 26 January 2021]

Barber, C.V, E Matthews, D Brown, T.H Brown, L Curran, and C Plume, The State of the Forest: Indonesia (Bogor, Indonesia, 2014) <https:/ / wriindonesia.org/sites/default/files/ keadaan_hutan_bab_2.pdf $>$

Brearley, Francis Q, Sukaesih Prajadinata, Petra S Kidd, and John Proctor, 'Structure and Floristics of an Old Secondary Rain Forest in Central Kalimantan, Indonesia, and a Comparison with Adjacent Primary Forest', Forest Ecology and Management, 195 (2004), 385-97

CNN Indonesia, 'KLHK Ungkap Perhutanan Sosial Baru Capai 4,4 Juta Hektare', Website, 2020 <https:/ / www.cnnindonesia.com/ nasional/20201208142543-20- 579403/ klhk-ungkap-perhutanan-sosial-baru-capai-44-juta- hektare> [accessed 18 January 2020]

DDDT news, 'Bidang Usaha Yang Tertutup Untuk Investasi Tinggal 6 Saja', Website, 2021 <https:// news.ddtc.co.id/bidang-usaha-yang- tertutup-untuk-investasi-tinggal-6-saja-28007?page_y=1004> [accessed 19 June 2021]

Dinas Lingkungan Hidup dan Kehutanan Yogyakarta, Buku Statistik Kehutanan Pemda DIY Tahun 2019 (Yogya- karta, Indonesia, 2019) < h t t p s : / / www.google.co.id / url?sa =t\&rc$\mathrm{t}=\mathrm{j} \& \mathrm{q}=\&$ esrc $=\mathrm{s} \&$ source $=w$ eb\&cd $=\& c a d=$ rja \&uact $=8 \& v e d=2 a-$ hUKEwjv3MGhuKXuAhU04XM BHdqXC5cQFjABegQIBBAC\&url=http\%3A\%2F\%2Fdlhk.jogjaprov. go.id\%2Fstorage\%2Ffiles\%2FBuku\%2520Data $\% 2520$ Statistik $\% 2520 \mathrm{~K}$ e h u t a n an\%2520DIY\%25202019.pdf\&usg=>

DNPI \& MC Kinsey, Indonesia's Greenhouse Gas Abatement Cost Curve (Jakarta, 2010) <https://photos. mongabay.com/10/indonesia_ghg_ cost_curve_en glish_sm.pdf>

Ekawati, Sulistya, and Dodik Ridho Nurrochmat, 'Hubungan Modal Sosial Dengan Pemanfaatan Dan Kelestarian Hutan Lindung', Jurnal Analisis Kebijakan Kehutanan, 11 (2014), 4053 <https://core.ac.uk/download/ pdf/191116032.pdf>

Ekawati, Sulistya, Dhani Yuniati, and Bugi K Sumirat, 'Hutan K e masyarakatan: Skema Tertua Pemberdayaan Masyarakat Sekitar Hutan', in Bersama Membangun Perhutanan Sosial, ed. by Sulistiya E k a wati, Sri Suharti, and Syaiful Anwar, I (Kota Bogor, Indonesia: I P B Press, 2020), pp. 7-8 < h t t p : / / simlit.puspijak.org/files/buku/ CROP_04- Membangun_Perhutanan_Sosial_FULL.pdf>

Ferdaus, R.M, P Iswari, E.D Kristianto, M Muhajir, T.D Dwiantoro, and S Septivianto, Rekonfigurasi Hutan Jawa: Sebuah Peta Jalan Usulan CSO (Y o gyakarta, Indonesia, 2014) 
Fisher, Micah R, Moira Moeliono, Agus Mulyana, E Linda Yuliani,

Andi Adriadi, Junaid Judda, and others, 'Assessing the New Social

Forestry Project in Indonesia: Recognition, Livelihood and C o n s e r v a tion?', International Forestry Review, 20 (2018), 346-61 <https:/ / doi. org/10.1505/146554818824063014>

Fitri, Rina Muhayah Noor, 'Reduksi Emisi Karbon Melalui Pengelolaan Hutan Alam Produksi Lestari', Jurnal Hutan Tropis, 1 (2013) < h ttps: / / ppjp.ulm.ac.id/journal/index.php/ jht/article/download /1487/1277>

Forest Digest, 'Lembar Fakta Omnimbus Law', Report, $2020<$ https: / / www.forestdigest.com/detail/842/ analisis-isi-uu-cipta- kerja> [accessed 27 January 2020]

Forest Watch Indonesia, Potret Keadaan Hutan Indonesia: Periode 2013-2017 (Bogor, Indonesia, 2019) <https:// fwi.or.id/wp- content / u ploads/2020/12/pkhi_-2013-2017_FWI. pdf $>$

Ge, Mengpin, and Johannes Friedrich, '4 Charts Explain Greenhouse Gas Emissions by Countries and Sectors', Website, $2020<$ https://www.wri. org/blog/2020/02/greenhouse-gas-emissions- by-country-sector $>$ [accessed 27 March 2020]

'4 Charts Explain Greenhouse Gas Emissions by Countries and Sectors', Website, $2020<$ https: / / www. wri.org/insights/4-charts- e x p lain-greenhouse-gas-emissions-coun- tries-and-sectors> [accessed 16 May 2021]

Hergoualc'h, Kristell, and Louis V Verchot, 'Stocks and Fluxes of Carbon Associated with Land Use Change in Southeast Asian Tropical P e a t lands: A Review', Global Biogeochemical Cycles, 25 (2011)

Indartik, I, N Parlinah, and M Lugina, 'Upaya Pembangunan $\mathrm{Hu}$ tan Tanaman Industri Untuk Penurunan Emisi Karbon', Jurnal Penelitian Sosial Dan Ekonomi Kehutanan, 8 (2011), 139-47 <http:/ / ejournal.forda-mof.org/ ejournallitbang/index.php/JPSEK/article/ view/228/219>

Integrated Law Enforcement Approach, 'Izin Usaha Pemanfaatan Hasil Hutan Kayu - Hutan Tanaman Industri (HTI)', Website, $2010<\mathrm{h} \mathrm{t} \mathrm{t} \mathrm{-}$ ps://www2.cifor.org/ilea/_ref/ina/ indicators/forestbusiness / P e r mit/IUPHHK-HTI.htm> [accessed 16 June 2021]

Irawan, U.S, and E Purwanto, Panduan Pengukuran Dan Pendugaan Cadangan Karbon Pada Ekosistem Hutan Gambut Dan Mineral (Bogor, Indonesia: $\quad$ Tropenbos Indonesia, 2020) <https://www.tropenbos- in d o nesia.org/file.php/2189/ti_panduan karbon_20200507.pdf>

Jpnn.com, 'Pangkas Birokrasi, UU Cipta Kerja Memudahkan Rakyat Dirikan UMKM', Online News, $2020<$ https:// www. jpnn.com/news/pangkas-birokrasi- 
-uu-cipta-kerja- memudahkan-rakyat-dirikan-umkm> [accessed 11 March 2021]

Kemenparekraf/ Baparekraf, Rencana Strategis Kemenparekraf/ Baparekraf 2020-2024 (Jakarta, Indonesia: Kementerian Pariwisata dan Ekonomi Kreatif/ Badan Pariwisata dan Ekonomi Kreatif, 2020) < h t tps://www.kemenparekraf.go.id/ asset_admin/assets/uploads / $\mathrm{m} \mathrm{e} \mathrm{-}$ dia/pdf/media_1598887965_Rencana_strategis_2020- 2024.pdf>

Kementerian Koordinator Bidang Perekonomian, Naskah Akademis RUU Tentang Cipta Kerja (Jakarta, Indonesia, 2020) <https://uuciptakerja.go.id/wp-content/uploads/2020/11/Naskah- A k a d e m i s -RUU-tentang-Cipta-Kerja.pdf>

Kementerian Lingkungan Hidup dan Kehutanan, Indonesia Third National Communication: Under the UNFCCC, ed. by N Masripatin (Jakarta, Indonesia: Ministry of Environment and Forestry, 2018) <https://unfccc.int/sites/default/ files/resource/8360571_Indones ia-NC3-2-Third National Communication - Indonesia - editorial refinement 13022018.pdf>

Statistik Kementerian Lingkungan Hidup Dan Kehutanan 2019 (Jakarta, Indonesia, 2020) < h t t p s: / / www.menlhk.go.id// site/download_file?file $=160800222$ 6.pdf $>$

Dan Kehutanan Tahun 2018 (Jakar- ta, Indonesia, 2019) < h t t p s:/ / www.menlhk.go.id// site/download_file?file $=157439530$ 5.pdf $>$

Latuihamallo, Joseph, and Jusmy D Putuhena, 'Analisis Nilai Guna Hu$\tan \quad$ Sebagai Penyedian Air Bersih Dan Implementasi PES (Payment for Ecosystem Service) Bagi Pemilik Dusun Di Hutan Lindung Gunung Sirimau Kota Ambon', JURNAL HUTAN PULAU-PULAU KECIL, 1 (2016), 44-52< h t t p s : / / ojs3.unpatti.ac.id/index.php/jhppk/ article/download/5 37/498>

Mai, Nguyen Thi Thanh, and Pham Thi Phuong, 'Production Relocation of Multinational Companies from China and Chances for Vietnam', $V N U$ Journal of Science: Economics and Business, 36 (2020) <https://js.vnu.edu.vn/EAB/article/download/4458/3986>

Mudhofir, Muhammad Rifqi Tirta, Bramasto Nugroho, and Sudarsono Soedomo, 'Kontrak Usaha Pemanfaatan Wisata Alam Pada Kesatuan Pengelolaan Hutan Lindung Rinjani Barat', Jurnal Pengelolaan Sumberdaya Alam Dan Lingkungan (Journal of Natural Resources and Environmental Management), 9 (2019), 419-36 < h t t p s: / / d o i . org/10.29244/jps1.9.2.419-436>

Mulyani, Mari, and Paul Jepson, 'Does the 'One Map Initiative'Represent a New Path for Forest Mapping in Indonesia? Assessing the Contribution of the REDD+ Initiative in Effecting Forest Gover- 
nance Reform', Forests, 8 (2017), 14 $<$ https://www.mdpi.com/1999$4907 / 8 / 1 / 14 /$ pdf $>$

Murdiyarso, D, K Hergoualc'h, I Basuki, S Sasmito, and B Hanggara, ' C a dangan Karbon Di Lahan Gambut', Leaflet, $2017<\mathrm{https}$ / / core. ac.uk/download/pdf/193250939. pdf $>$ [accessed 17 May 2021]

Murdiyarso, Daniel, Daniel Donato, J Boone Kauffman, Sofyan Kurnianto, Melanie Stidham, and Markku Kanninen, 'Carbon Storage in Mangrove and Peatland Ecosystems: A Preliminary Account from P 1 o t s in Indonesia', Working Paper 48. Bogor Banat, Indonesia: Center for International Forestry Research. 35 P., 2009, 1-35

Nandini, Ryke, 'Evaluasi Pengelolaan Hutan Kemasyarakatan (HKm) Pada Hutan Produksi Dan Hutan Lindung Di Pulau Lombok', Jurnal Penelitian Hutan Tanaman, 10 (2013), 43-55 $<$ http://ejournal.forda- $\mathrm{m}$ of . org/ejournal- litbang/index.php/ JPHT/article/download/100/95>

Nanggara, S.G, M.F Barri, L Rosalina, I Apriani, A.R Oktaviani, P Pay, and others, Silang Sengkarut Pengelolaan Hutan Dan Lahan Di Indonesia, ed. by A.C Ichsan and E Cayhono, 2018th edn (Bogor, Indonesia: Forest Watch Indonesia, 2018) <https:// fwi.or.id/wpcontent/uploads/2018/03/Dummy_15Maret2018_Silang_Sengkar ut.pdf>

Nurdjanah, N, 'Emisi CO2 Akibat Kenda- raan Bermotor Di Kota Denpasar', Jurnal Penelitian Transportasi Darat, 16 (2014), 189-202 <https:// doi. org/10.25104/jptd.v17i1.135>

Palm, Cheryl A, P L Woomer, J Alegre, L Arevalo, C Castilla, D G Cordeiro, and others, 'Carbon Sequestration and Trace Gas Emissions in Slashand-Burn and Alternative Land Uses in the Humid Tropics', 1999

Pawitan, Hidayat, 'Perubahan Penggunaan Lahan Dan Pengaruhnya Terhadap Hidrologi Daerah Aliran Sungai', in Prosiding Seminar $M u l$ tifungsi Pertanian Dan Konservasi Sumber Daya Lahan (Bogor, In d onesia: Balittanah-KEMENTAN, 2004) $<$ http://balittanah.litbang.pertanian. go.id/ind/dokumentasi/prosiding/ mflp2004/hidayat pawitan.pdf>

Pramono, I.B, Orasi Pengukuhan Profesor Riset Bidang Hidrologi Hutan: Peningkatan Peran Hutan Dalam Mengendalikan Hasil Air Untuk Mitigasi Banjir Dan Kekeringan, ed. by I Rahmawati (Bogor, Indonesia: Badan Penelitian, Pengembangan dan Inovasi Kementerian Lingkungan Hidup dan Kehutanan, 2020) <https://library.forda- mof.org/libforda/ foto_ebook/ORASI_IRFAN_Final-1. pdf $>$

Prasetio, Teguh, and Maharani Nurdin, 'Kewenangan Konkuren Pemerintah Daerah Dalam Perizinan Industri Berdasarkan Undang- U n dang No. 11 Tahun 2020 Tentang Cipta Kerja', Kertha Semaya: Journal Ilmu Hukum, 9, 314-29 <https:/ / doi. 
org/10.24843/KS.2021.v09.i02.p11>

Renggono, Findy, and M Djazim Syaifullah, 'Kajian Meteorologis Bencana Banjir Bandang Di Wasior, Papua Barat', Jurnal Meteorologi Dan Geofisi$k a, 12$ (2011)

Roshetko, James M, Matt Delaney, Kurniatun Hairiah, and Pratiknyo

Purnomosidhi, 'Carbon Stocks in Indonesian Homegarden Systems: Can Smallholder Systems Be Targeted for Increased Carbon Storage?', American Journal of Alternative Agriculture, 2002, 138-48

Rosyidie, Arief, 'Banjir: Fakta Dan Dampaknya, Serta Pengaruh Dari P e r u bahan Guna Lahan', Jurnal Perencanaan Wilayah Dan Kota, 24 241-49

Saragih, Ivany Gresya, Made Sudiana Mahendra, and I Made Sudarma, 'Valuasi Ekonomi Jasa Lingkungan Ekosistem Hutan Taman Eden 100, Desa Lumban Julu, Parapat, Sumatera Utara', ECOTROPHIC: Jurnal Ilmu Lingkungan (Journal of Environmental Science), 13 (2019), $\quad$ 170-79 <https:/ / doi. org/10.24843/EJES.2019.v13.i02.p05>

Siregar, Efrem, 'Duh! Izin Di RI Ribet, Investor Industri Kayu Batal Investasi', Online News, $2020<$ https://www.cnbcindonesia.com/news/20200103201644-4127581/duh-izin-di-ri-ribet-investor-industri-kayu-batal-investasi> [accessed 6 April 2020]
Subarudi, Hariadi Kartodihardjo, Sudarsono Soedomo, and Hadiyanto Sapardi, 'Kebijakan Resolusi Konflik Tambang Batubara Di Kawasan Hutan Di Kalimantan Timur', Jurnal Analisis Kebijakan Vol, 13 (2016), 53-71 <https://doi.org/10.20886/ jakk.2016.13.1.53-71>

Sulaeman, D, A Pradana, and H Hamzah, 'Tiga Faktor Utama Penyebab Banjir Di Indonesia Dan Bagaimana Mencegahnya', Website, $2019<$ https://wri-indonesia. org/id/blog/3-faktor-utama-penyebab- banjir-di-indonesia-dan-bagaimana-mencegahnya> [accessed 27 January 2021]

Tempo.co, 'Tingkat Pengangguran Sampai 2, 56 Juta Orang, Kepala BPS: Imbas Pandemi Covid-19', Online News, $2021 \quad<$ h t t p s: / / bisnis.tempo.co/read/1444706/tingkat-pengangguransampai-2-56-juta-orang-kepala-bps-imbas-pandemi-covid-19> [accessed 11 March 2021]

The Economic Times, 'Trade War: Why Manufacturers Are Not Rushing into India, Indonesia', Website, $2019<$ <ttps://cfo.economictimes.indiatimes.com/news/ trade-war- why-manufacturers-are-not-rushing-into-india- in d o nesia/71477654> [accessed 5 February 2021]

Utami, Larasati D, 'KLHK Optimis Omnibus Law Tingkatkan Kinerja U s a ha Sektor Kehutanan', Online News, 
$2020<$ https: / / www.tribunnews.com/nasional/2020/12/02/ klhk- optimis-omnibus-law-tingkatkan-kinerja-usaha-sektor-kehutanan> [accessed 11 March 2021]

Wahyudi, E, 'Indef Nilai RUU Cipta Kerja Berpotensi Kurangi Pendapatan Daerah', Website, $2020<\mathrm{https}:$ / / www.cnnindonesia.com/ ekonomi/20201026202156-532- 563008/ indef-sebut-omnibus-law-bisa-gerus-pendapatan-daerah> [accessed 5 February 2021]

Wibowo, Ari, 'Konversi Hutan Menjadi Tanaman Kelapa Sawit Pada Lahan Gambut: Implikasi Perubahan Iklim Dan Kebijakan',
Jurnal Penelitian Sosial Dan Ekonomi Kehutanan, 7 (2010), 251-60 $<$ http:/ / ejournal.forda-mof.org/ ejournal- litbang/index.php/JPSEK/ article/view/242/233>

Widiaryanto, Pungky, 'Rasionalitas Kebijakan Konsepsi Hutan Dan Penghapusan Batas Minimal Kawasan Hutan 30 Persen', GEMA PUBLICA: Jurnal Manajemen Dan Kebijakan Publik, 5 (2020), 140-55 < h t t p s : / / doi.org/https://doi.org/10.14710/ gp.5.2.2020.140-155> 